\title{
THE INFLUENCE OF ENTREPRENEURIAL ORIENTATION ON BUSINESS STRATEGY AND PERFORMANCE OF MEDIUM-SMALL SCALE SASIRANGAN INDUSTRIES IN SOUTH KALIMANTAN PROVINCE
}

\author{
Maskur \\ Islamic University of Muhammad Arsyad Al Banjari Kalimantan, \\ Banjarmasin, South Kalimantan, Indonesia \\ E-mail: maskursariman@yahoo.co.id
}

\begin{abstract}
This study aimed at investigating the direct influence of entrepreneurial orientation on business strategy and the performance of medium-small scale industries. This study was conducted to Sasirangan medium small scale industries in South Kalimantan. There were 83 samples used in this study that were chosen using the purposive sampling method from 3 cities or districts in South Kalimantan (Banjarmasin, Banjarbaru and Martapura). Data of this study were collected through observations, questionnaires and direct interview with medium small scale Sasirangan business owners using interview guidelines. Secondary data were obtained from the Government of South Kalimantan Province and other related institutions. The obtained data were analyzed using the GSCA (Generalized Structured Component Analysis). The results of the data analysis show that entrepreneurial orientation significantly and directly gives positive influence to business strategy and business performance of the industries. Furthermore, business strategy also appears to have direct positive and significant influence to the performance of the industries.
\end{abstract}

\section{KEY WORDS}

Business performance, business strategy, entrepreneurial orientation, South Kalimantan.

Medium small scale industry is a part of entrepreneurship. This type of industry has been known to successfully survived the economic crisis in Indonesia. Indonesia faced a major economic crisis which caused stagnancy to large-scale industries. However, during the crisis, small and medium scale industries had stronger protection to survive. This phenomenon has raised optimism to developing countries to improve their economic condition (Altinay and Wang, 2011). Empowerment of medium small scale industries is considered necessary to do in both developed and developing countries since it holds a crucial role in the development of a nation's economy. The medium small scale industries also have better adaptability in adjusting to the fluctuation of economic condition (Kaballu and Kameo, 2001). Besides, the industries also give strong contribution to the employment program (Tambunan, 2005). According to Price (2004), medium small scale industries make $51 \%$ contribution to the gross domestic product of private sectors and dominate $47 \%$ of business transaction.

Medium small scale industries also experience various problems. Kirby and Kaiser (2003) stated that the industries usually suffer from some issues including the lack of entrepreneur values, funding, marketing and other external factors such as the macroeconomic condition, legal policies, and fulfillment of the facilities that influence the growth of this sector. According to Teck (2012), owners of this sector usually established their enterprises due to personal economic motives or issues that had them become less creative in running their business because most of them focused on only the profit rather than the growth of the business itself. In another word, environmental business factors were less considered.

Considering the importance of determining entrepreneurial orientation in order to achieve better competitiveness and success of the business, medium small scale industries should improve their entrepreneurial orientation in running their business activities which can also be used as the base in designing and implementing the best strategies to face the tight 
business competition. Zhi and Jintong (2012) explained that companies that apply business strategies based on clear entrepreneurial orientation through innovation, dare to take any risks, and proactive attitude in conducting their activities tend to have better response to business fluctuation that occurs. It is also stated by Gurbuz and Aykol (2009) that small-scale industries with better entrepreneurial orientation tend to apply precise strategies in running their business which results to better performance capability in facing the competitive competition. Several empirical studies have shown direct influence of entrepreneurial orientation on the improvement of business strategy and business performance (Litunen dan Nittykangas, 2010; Zhi dan Jintong , 2012; Boso et al., 2013; Gurbuz and Aykol, 2009 ). Precise business strategy is important to applied in medium small scale industries since they are required to be keen on identifying any possible opportunities and threats in their business environment. Determination of the precise business strategy also gives positive contribution to excellence business performance and achievement.

\section{LITERATURE REVIEW}

Entrepreneurial Orientation. Zhai and Jintong (2012) stated that companies with entrepreneurial orientation are the antecedents of business strategy implementation through innovation, risk taking and proactive attitude in performing their business, which lead them to have better ability in facing the dynamic market condition. Gurbuz and Aykol (2009) emphasized that entrepreneurial orientation is the key to enhance the business performance.

Lumpkin and Dess (1996) Wiklund and Shepperd (2005) stated that entrepreneurship deals with strategic orientation covering some aspects of entrepreneurship including the style, method and innovative actions to make a change. Gurbuz and Aykol (2009) also highlighted that entrepreneurial orientation is the key to enhance the performance.

Zimmerer and Scarborough (2002) mentioned that owners of small-scale industries have the belief that hard work to develop their own enterprises makes them happier than being employed by big companies. McGrath (1999) mentioned that companies with entrepreneurial orientation have stronger potential to make more profitable variations in business performance in long term when the variations are integrated with other strategies.

Meredith et al. (2005) explained that entrepreneurs are people who have the ability to predict and analyze any business opportunities, provide any necessary resources to make higher profit and to take the best steps to be successful. Entrepreneurs have made positive changes in the business world by showing never-give-up attitude in facing any obstacles in order to achieve the goals of the companies which have been previously planned (Machfoedz, 2004). This attitude is regarded as a reflection of entrepreneurial orientation which reflects managerial capability through innovation, risk taking, and being proactive in running the business (Miller, 1983). Entrepreneurs with entrepreneurial orientation are relatively capable in identifying any opportunities and implementing the most appropriate business strategy to advantages from the opportunities.

Business Strategy. Gurbuz and Aykol (2009) stated that small-scale industries which have the entrepreneurial orientation tend to apply various appropriate strategies and management system in running the business which result to better performance in facing the tight market competition. Furthermore, companies are also able to make profit from being keen on identifying opportunities in the business environment and eventually develop the competitiveness of the companies by implementing effective strategies (Bastian and Muchlish, 2012). Zhi and Jintong (2012) also stated that companies which apply certain business strategies in running the business tend to remain strong even in the ever-changing business condition.

Business strategy has been continuously discussed in the field of micro-business seen from the conservative point of view up to the proactive-reactive one (Covin and Slevin, 1991). Review on the literature related to strategic planning and business performance shows that performance obtained higher level than proactive companies but it did not improve the strategy (Covin and Slevin, 1991). 
Kotler (2002) defined strategy as a plan to achieve certain business goal done by a company. Every business unit has to plan a strategy to achieve its goals including the marketing strategy, technology advancement strategy and resource management strategy. Porter (2005) explained that in order to win the market competition, a business unit should concentrate to crate; (1) cost leadership, in which a company should set lower product price compared to other competitors. (2) differentiation, in which a company should focus on the product, and (3) focus, in which cost leadership or differentiation are used to focus on certain specific market or customers.

The Performance of Medium Small-Scale Industries. Chakravarthy (1986) stated that corporate performance is a construct that is generally used to measure the effect of certain strategic orientation applied in a company. Pelham and Wilson (1996) defined performance as the success of a new product released to the market by a company and market developer that can be measured from the growth of sale and market share.

A study done by Bittici, et al. (2000) explains that business performance is measurable through the sales, sale expenses, assets, product images, and fixed assets owned by a company.

Conceptual Framework. Seong (2011), Zhi and Jintong ( 2012), Gurbuz and Aykol (2009) have measured significant influence of entrepreneurial orientation consisting of innovativeness, proactiveness and risk taking toward business performance that covered sales growth, profit improvement, asset growth. Lee and Tsang (2001) have conducted a study on the influence of entrepreneurial orientation emphasizing on the characteristics of the businessman including the indicator of entrepreneur personality, entrepreneur's background and network activity toward business performance that consisted of sale growth, profit improvement, and asset growth which show different results.

Gurbuz and Aykol (2009) explored the role of entrepreneurial orientation (EO) to the corporate performance which resulted an alternative contingent model which proposes the role of mediation seen from the managerial orientation factor to the relationship between entrepreneurial orientation and corporate performance, as well as the factors of managerial orientation which directly influences the performance.

Accordingg to Hashim et al. (2001), effectiveness of a strategy can be measured by investigating the business environment. Hence, business strategic should be synchronous with the organizational environment to achieve excellent performance. Other research supporting the implementation of entrepreneurial orientation and its correlation with corporate performance was done by Galetić and Milovanović (2004). In their study, they used the term entrepreneurial orientation to refer to the process of strategic planning and the styles applied by companies in running their business. The result of their study show a positive correlation between entrepreneurial orientation and business performance measured from sales growth in hotels in Coratia. Research supporting the implementation of entrepreneurial orientation and its correlation with corporate performance was conducted by Galetić dan Milovanović (2004). In the research, entrepreneurial orientation was used to refer to the process of strategy planning and management style in running a business. The result of the study indicated a positive correlation between entrepreneurial orientation and performance seen from sales growth as the indicator done in Hotels in Croatia.

Hashim et al. (2011) explored the role of business strategy to business performance which resulted to an alternative contingent model. The model emphasizes the role of mediation among environmental factors within the correlation between business strategy and performance and it also taps on the direct influence of business strategy on performance.

Dani et al. (2013) also explored the role of management ability to business performance which resulted to an alternative contingent model as presented in Figure 3.3. Furthermore, the alternative contingent model proposed by Dani et al. (2013) focuses on the role of management ability which directly influences the business performance. The available models can be used as the base in designing the conceptual framework, yet they cannot be simply adopted without modifications.

Suci (2009) conducted a study on the improvement of business performance through entrepreneurship and business strategy. The result of the data analysis showed that 
business strategy has certain influence on the performance. Meanwhile, Hashim (2000) mentioned that the performance of SMEs in Malaysia varied due to different preferences of business strategy adopted by the companies.

Based on the review of the related literature, considering the results of previous research and the research framework of this matter, 3 hypotheses of this study were formulated as follow:

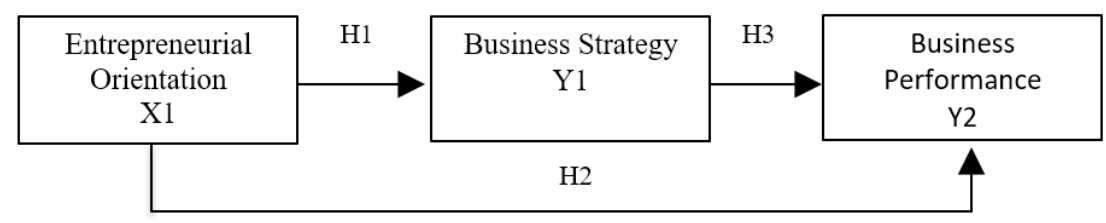

Figure 1 - The Conceptual Framework of this Study

Research Hypotheses:

$\mathrm{H} 1$ : Entrepreneurial orientation significantly influences business strategy;

$\mathrm{H} 2$ : Entrepreneurial orientation significantly influences the performance of medium small scale industries;

H3: Business strategy significantly influences the performance of medium small scale industries.

\section{METHODS OF RESEARCH}

This study employed a quantitative approach (positivism) since the data obtained from the survey were numerical data which were later analyzed using the statistical measurement to answer the research questions and to test the research hypotheses. Results of the statistical test were used to explain the position of the research variables and to predict the relationship between the variables (Creswell, 2009).

This study was generally aimed at testing and explaining the influence of entrepreneurial orientation on business strategy and business performance in medium small scale industries. Regarding to the objectives of this study, this study is regarded as an explanatory research. Explanatory research is conducted by identifying the facts or phenomena related to certain object in order to provide thorough explanation on the phenomena based on the interaction between the variables of the study (Sugiono, 2008). In addition, this research is also a cross-sectional research in which reviews were done based on certain perception and information provided by informants at the same time.

The population of this study was 86 owners of medium small scale Sasirangan industries in South Kalimantan who were also participated as the samples of this study (census). Act Number 20 of 2008 mentioned that small scale industries are productive independent enterprises and are not branches of other companies owned and manage directly or indirectly by medium scale industries or large scale industries. Small scale industries have characteristics which are mentioned in the Act Number 20 of 2008.

The data obtained in this study were then analyzed using descriptive analysis and inferential statistic measurement namely the Generalized Structured Component Analysis (GSCA). Primary data were collected from the questionnaires distributed to the respondents who were owners or managers of Sasirangan small scale industries based on the instruments used in this study. Whilst, secondary data were obtained from the Department of Industries of South Kalimantan, Central Bureau of Statistics, and other related institutions.

\section{RESULTS AND DISCUSSION}

The Influence of Entrepreneurial Orientation on Business Strategy. Entrepreneurial orientation was found to have a positive, direct and significant influence on business strategy. The result fo GeSCA test shows path coefficient at 0.215 and CR $4.22^{*}$ (significant 
with positive mark). Hence, it implies that entrepreneurial orientation applied in small scale Sasirangan industry directly improves the business strategy. Both variables share a positive relationship which means that entrepreneurial orientation in the forms of innovation, risk taking and proactive attitude lead the companies to find better and more precise business strategy. It can be understood that the determination of business strategy gets better as the implementation of entrepreneurial orientation enhances.

The finding of this study describes that in order to create better competitiveness to compete in the ever changing business condition, companies need to set precise orientation to overcome various obstacles in running the business. Success of small scale companies can also be achieved by implementing appropriate business strategies. Meredith et al. (2005) stated that entrepreneurs are people who have the ability to predict and take any opportunities, manage the available resources to obtain higher profit and take precise actions to achieve the success. Entrepreneurs have brought significant changes in business world by showing tough attitude in dealing with obstacles and issues in order to achieve success through a set of well-planned strategy (Machfoedz, 2004). This attitude is regarded as entrepreneurial orientation that reflects managerial ability through innovation, risk taking and proactive actions in running a business (Miller, 1983). Entrepreneurs with adequate entrepreneurial orientation are relatively capable in implementing the best business strategy to make the most out of the available opportunities.

The result of this study supports the finding of a study done by Oscar et al. (2009) which result shows that entrepreneurial orientation positively influences the market orientation. Suci (2009) also found that entrepreneurial orientation has a positive and significant influence on the business strategy. Therefore, it can be implied that higher entrepreneurial orientation provides easiness for a company to focus and implement the appropriate business strategies including differentiation, low budget and focus. Each of the strategy can be used as a single strategy or it can be combined one with another to obtain the most precise strategy. Furthermore, this study also supports Lee \& Tsang (2001) which result of the statistical analysis shows that a small organization which applied organizational transformation and strategic innovation through creation and combination of competence is also influenced by owner's characters, and the strategic attitude reflects the characters of a small business owner. The result of this study also supports the ones conducted by Litunen \& Nittykangas (2010); Seong (2011); Dani (2013) who confirmed that entrepreneurial orientation directly influences the business strategy.

Theoretically, the result of this study goes in line with the one found by Storey (1994) in which it is stated that the development of entrepreneurial orientation is necessary in reviewing business strategies applied by medium small scale industries. This point is emerging since personal attribution of a business owner has a strong influence in the determination and implementation of certain business strategies. Zhi and Jintong (2012) also support this view in which it is indicated that companies with entrepreneurial orientation tend to be the antecedent of business strategy implementation through innovation, risk taking and proactive attitude in running the enterprise. As the result, those companies eventually found and implement the best strategy to face the dynamic business environment. Similar view was proposed by Gurbuz and Ayikol (2009) that medium small scale business with entrepreneurial orientation tend to apply the most effective strategy which eventually gives better business performance to compete and win the competition.

The Influence of Entrepreneurial Orientation on the Performance of IKM. Entrepreneurial orientation has been found to have a direct significant and positive influence on the performance of IKM. The result of GeSCA test obtained a path coefficient at 0.250 and $\mathrm{CR}=8.30^{*}$ (significant) with positive mark. It implies that the implementation of entrepreneurial orientation in Sasirangan small business directly enhances the performance of the enterprises. This also shows that the implementation of entrepreneurial orientation combined with the application of appropriate business strategy even accelerates the improvement of IKM performance. This finding motivates owners to make innovations, dare to take risks, and to become proactive in order to let entrepreneurial orientation improve the sales growth, higher profit and grow the capital as the variables of IKM performance. This 
finding is empirically supported by the fact that the better the entrepreneurial orientation the better the performance of IKM. This result also reflects that well-managed entrepreneurial orientation is able to improve the performance of Sasirangan IKM in South Kalimantan.

The finding of this study also supports findings of previous research such as the one conducted by Litunen and Nittykangas (2010) who investigated the influence of entrepreneurial orientation on performance which finding shows that the entrepreneurial orientation has a positive and significant influence on the development of business companies. Similarly, Zhi and Jintong (2012) have measured the influence of entrepreneurial orientation on business performance. The result of their study shows that indicators of entrepreneurial orientation including the innovativeness, risk taking and proactive attitude positively influence the performance of medium small scale business (SME's). In addition, the result of this study also supports the findings of Boso et al. (2013); Dani (2013); Gurbuz and Aykol ( 2009), Suci (2011) which state that entrepreneurial orientation directly gives positive contribution to corporate performance.

The result of this study is also in line with McGrath (1999) which states that companies with good entrepreneurial orientation have higher potential to obtain variety of performance which is profitable in longer term when it is integrated with appropriate business strategies. Stainhoff and Burgess (1993) mentioned some characteristics of successful business: having clear corporate visions and missions, willing to take risks of time and money, working based on clear plan and organization, working hard based on the level of priority, enhancing the relationship with the customers, suppliers, employees and being responsible upon corporate's success and failure.

The Influence of Business Strategy on the Performance of IKM (H7). Business strategy positively and significantly influences the performance of IKM. The result of GeSCA obtained a path coefficient at $0.571^{*}$ and $C R=17.99^{*}$ (significant) with positive mark. This result means that implementation of appropriate business strategy in Sasirangan small business is able to improve its performance. This also implies that the more appropriate implementation of low-budget strategy, differentiation, and focus strategy as the variables of business strategy would be stronger in improving the sales growth, profit growth, and capital growth which are the variables of business performance.

The finding of this study adds up to the body of knowledge especially on the theory of Pierce II and Robinson (2007) in which it is defined that strategic management is a set of decisions and actions to plan certain steps to achieve certain corporate's goals or objectives. The path of strategic management forms certain order of decisions and actions which are oriented at determining one or more than one strategies that are considered effective to achieve the corporate goals or objectives (Jauck and Glueck, 1988). This study also strengthens the research finding of Parnell (2010) who investigated the relationship between business strategy and business performance of retailers in The United States and their complexities. The result of this study shows a positive and significant influence of business strategy on business performance within a relatively short time and it is found that better business performance gives better profit in the long term. In line with this finding, Acquaah (2013) has confirmed that business strategy influences the organizational performance of family-owned business. Some other research including the ones conducted by Man dan Wafa (2008), Bordean et al. (2010), Mohd et al. (2013), Hsu (2012), Li and Tan (2013) have also confirmed the positive and significant influence of business strategy on business performance.

\section{CONCLUSION AND SUGGESTIONS}

Based on the result of this study, conclusions are drawn as follow:

Entrepreneurial orientation applied by owners of Sasirangan IKM owners has been confirmed to support the business strategy. This means that entrepreneurial orientation directly influences the implementation of business strategy. It also reflects that owners of Sasirangan IKM who have entrepreneurial orientation tend to apply more appropriate business strategy in running their business. Furthermore, if they apply innovation, dare to 
take risks and become proactive, they would be highly capable in identifying any business opportunities which create better competitiveness by implementing appropriate business strategy.

The implementation of entrepreneurial orientation in Sasirangan IKM has been proven to improve the performance of $I K M$. Thus, it is implied that entrepreneurial orientation directly influences the performance of IKM. The finding of this study is also supported by the empirical fact that the better the implementation of entrepreneurial orientation, the better the performance of $I K M$. This finding shows that well-managed entrepreneurial orientation gives better contribution to the performance of IKM in South Kalimantan Province.

Overall, the result of this study shows that entrepreneurial orientation and business strategy have significant influence on business performance.

Regarding to the result of this study, the discussion, and the limitation of this study, suggestions were made as follow:

Effectiveness of entrepreneurial orientation in improving the capability of Sasirangan IKM owners can be obtained by implementing innovation, dare to take risk, and being proactive which appear to be positive characteristics of entrepreneurs in improving their performance.

Companies should stay innovative in implementing their business strategy which is the crucial component that determines the business sustainability. Therefore, Sasirangan IKM should always try to find effective ways in promoting their products by acting proactive in running their business and try to produce high quality products with high competitiveness and uniqueness and they are also suggested to utilize the advancement of technology to make the production more effective and efficient.

\section{REFERENCES}

1. Acquaah Moses. 2013. "Management control System, Business Strategy and Performance: A Comparative Analysis of Family and Non-family Business in a Transition Economy in Sub-Saharan Africa”, Journal of Family Business Strategy, Vol. 4 pp.131146.

2. Altinay, Levent and Wang, Catherine L. 2011. "The Influence of an Entrepreneur's Sociocultural Characteristics on The Entrepreneurial Orientation of Small Firms", Journal of Small Business and Enterprise Development, Vol. 18, No. 4, Emerald Group Publishing Limited, pp. 673-694.

3. Bastian, Alvin, Muchlish Munawar. 2012. "Perceived Environment Uncertainty, Business Strategy, Performance Measurement Systems and Organizational Performance", Procedia-Social and Behaviour Science No.65, pp.787-792.

4. Bititci, Umit S., Trevor Turner dan Carsten Begemann, 2000, Dynamics of performance measurement systems, International Journal of Operations \& Production Management, Vol. 20 No. 6, pp. 692-704.

5. Bordean, Ovidiu N., Anca I. Borza, Razvan L. Nistor, and Catalina S. Mitra., 2010. "The Use of Michael Porter's Generic Strategies in the Romanian Hotel Industry", International Journal of Trade, Economics and Finance vol 1 no 2. Business Performance: A Configurational Approach, Journal of Business

6. Chakravarthy, Balaji S., 1986, Measuring Strategic Performance, Strategic Management Journal, Vol. 7, No. 5, pp. 437-458. Construct and Linking It to Performance, The Academy of Management Review, Vol. 21, No. 1, (Jan., 1996), pp. 135-172.

7. Covin, Jeffrey G. dan Dennis P. Slevin, 1991, A Conceptual Model of Entrepreneurship As Firm Behavior, Baylor University.

8. Cresswell, John W., 2009, Reseach Design: Qualitative, Quantitative and Mixed Methode Approaches. Third Edition, Sage Publication Inc., California.

9. Dani, Ibrahim, Idrus, M.S., Nimran, Umar, Sudiro, Achmad, 2013. "Business Strategy Role as Mediation of Management Capability and Orientation of Entrepreneurship on Business Performance (A Study on Micro and Small Scale Seaweed Business in Takalar 
District, South Sulawesi Province). Journal of Management Reseach ISSN 1941-899x, Vol.5, No.1

10. Galetić, Fran dan Bojan Morić Milovanović, 2004, Linking Entrepreneurial Orientation With The Performance Of Croatian Hotel Industry, Faculty of Economics and Business, Working Paper, 2004

11. Gurbuz, Gulruh and Aykol, Sinem, 2009. "Entrepreneurial Management, Entrepreneurial Orientation and Turkish Small Firm Growth", Management Research News Vol 32, No 4. Emerald Group Publishing Limited, pp.321-336

12. Gurbuz, Gulruh and Aykol, Sinem, 2009. "Entrepreneurial Management, Entrepreneurial Orientation and Turkish Small Firm Growth", Management Research News Vol 32, No 4. Emerald Group Publishing Limited, pp.321-336

13. Hashim M K, S. A. Wafa and M. Sulaiman. 2001. "Testing Environment as Mediator Between Business Strategy-Performance Relationship: A Study of Malaysian SMEs", 46th ICSB World Conference - jan 17-20 2001, Taipei, Taiwan.

14. Hsu, Shu Hung, 2012. "Effects of Competitive Strategy, Knowledge Management and EBusiness Adoption on Performance". The Journal of Human Resource and Adult Learning, Vol. 8, Num. 2.

15. Jauch L.R, and Glueck W.F, 1988, Business Policy and Strategic Management, McGraw Hill, New York. pp.466-483.

16. Kaballu, O.U., dan Kameo, D.D. 2001. "Strategi Bertahan Usaha Kecil Dalam Menghadapi Krisis Ekonomi (Studi Industri Kecil Konveksi di Salatiga)", Dian Ekonomi, VII (2), September 2001: 191 - 205

17. Kirby, D.A., and Kaiser, S. 2003: Joint Venture as an internationalization strategy for SME; Small Business Economics 21, pp. 229-242

18. Kotler P., 2002, Manajemen Pemasaran, Edisi Millenium, Jilid 1, Jakarta, PT. Prenhallindo.

19. Lee D. Y. and Tsang E. W. K. 2001, "The effect of Entrepreneurial Personality, Background and Network Activities on Venture Growth", Journal of Management Studies 38-4 pp 583-602.

20. Li, Yan and Tan Chuan-Hoo 2013."Matching Busines Strategy and ClO Characteristics: The Impact on Organizational Performance", Journal of Business Research Vol.66, pp.248-259.

21. Littunen, Hannu, Niittykangas, Hannu. 2010. "The Rapid Growth of Young Firms During Various Stages of Entrepreneurship", Journal of Small Business and Enterprise Development, Vol. 17, No.1, Emerald Group Publishing Limited, pp. 831.

22. Lumpkin, G. T. dan Gregory G. Dess, 1996, Clarifying the Entrepreneurial Orientation

23. Machfoedz, M., 2004. Kewirausahaan Suatu Pendekatan Kontemporer, Penerbit YKPN. Yogyakarta.

24. Man, Mandy Mok Kim and Wafa Syed Azizi. 2008. "The Relationship Between Distinctive Capabilities, Innovativeness, Strategy Types and the Performance of Small and Medium: Size Enterprises (SMEs) on Malaysian Manufacturing Sector", The Journal of American Academy of Business vol.13.

25. McGrath, R.M., 1999, Falling Forward: Real Option Reasoning and Entrapreneurial Failure, Academy of Management Review, 24: 12-30

26. Meredith. G.G., Nelson, R.E., and Neck, P.A., 2005. The Practice of Entrepreneurship, Genewa. International Labor Organization.

27. Miller, D., 1983, The Correlates of Entrepreneurship in Three Types of Firms, Management Science, Vol 29, No.7, pp. 770-791

28. Mohd, Wael, Subhi Idris, Raed A. Momani. 2013. "Impact of Environmental Dynamism on Marketing Strategy Comprehensiveness and Organizational Performance", International Journal of Business an Management; Vol.8 No.9.

29. Oscar, Gonzalez-Benito, Javier Gonzalez-Benito and Pablo A. Munoz-Gallego, 2009. "Role of Entrepreneurship and Market Orientation in Firms' Success. European Journal of Marketing Vol. 43 No. 3/4, 2009 pp. 500-522. Emerald Group Publishing Limeted. 
30. Parnell, John A., 2010. "Strategic Clarity, Business Strategy and Performance, Journal of Strategy and Management", Vol 3, No 4, Emerald Group Publishing Limited, pp.304-324.

31. Porter E.M., 2005, Competitive Strategy, Collier Macmillan. Release:1998

32. Price, Robert W., 2004. Roadmap to Entrepreneurial Success: Powerful.

33. Seong, Jee Young. 2011. "The Effects of High Performance Work Systems, Entrepreneurship and Organizational Culture on Organizational Performance", Seoul Journal of Business, Vol.17, Num.1.

34. Steinhoff D., and Burges J.F.,1993. Small Business Management Fundamental, McGrawHill, New York.

35. Storey, D.J., 1994, Undestanding The Small Business Sector, London, Routledge. Strategies for Building a High-Profit Business, Publishing: AMACOM

36. Suci, Rahayu Puji, 2009, Peningkatan Kinerja melalui Orientasi Kewirausahaan, Kemampuan Manajemen, dan Strategi Bisnis, Jurnal Manajemen dan Kewirausahaan. Vol.11, No.1, Maret 2009, 46-58

37. Sugiono, 2008, Metode Penelitian Bisnis, Cetakan Ke- dua Belas, Penerbit Alfabeta, Bandung.

38. Tambunan T.H, 2000, Perekonomian Indonesia - beberapa Isu Penting, Ghalia Indonesia.

39. Teck, Pua Eng. 2012. "Entrepreneurial Market Orientation Relationship to Performance: Malaysian SME's perspective, Journal of Asia Entrepreneurship and Sustainability, Vol VIII Iss 1 May Venturing 20 (2005) 71-91. Wiklund, Johan dan Dean Shepherd, 2005, Entrepreneurial Orientation And Small

40. Zhi, Tang and Jintong, Tang, 2012" Entrepreneurial orientation and SME performance in China's changing environment: The moderating effects of strategies". Springer Science Business Media

41. Zimmerer, Thomas W. and Scarborough, Norman M., 2002, Pengantar Kewirausahaan dan Manajemen Usaha Kecil. Prenhallindo, Jakarta. 